\title{
Efektivitas Dosis Dan Aplikasi Pupuk Npk Majemuk Pada Fase Vegetatif Pada Tanaman Strawberry (Fragaria $x$ ananassa Duchesne)
}

\author{
Norry Eka Palupi, Titistyas Gusti Aji, Dwi Kurnilasari dan Sutopo \\ Balai Penelitian Tanaman Buah Jeruk dan Tanaman Buah Subtropika \\ Indonesian Citrus and Subtropical Fruit Research Institute (ICSFRI) \\ JI. Raya Tlekung no. 1, Junrejo, Batu, Jatim. P.O Box 22 Batu, JawaTimur, Indonesia \\ email: balitjestro@litbang.deptan.go.id; balitjestro@gmail.com; \\ 3ch4lupi.jestro@gmail.com
}

\begin{abstract}
Abstrak
Pengelolaan hara merupakan salah satu faktor penentu hasil dan kualitas buah yang tinggi. Selama ini, rekomendasi pupuk untuk tanaman stroberi menggunakan NPK 16-16-16. Pemupukan NPK 16-16-16 masih kurang mencukupi, sehingga petani masih menambahkan pupuk $\mathrm{KNO}_{3}$. Oleh karena itu, perlu dilakukan pengujian terhadap pupuk NPK dengan komposisi berbeda yaitu dengan porsi K lebih tinggi (NPK 12-6-24). Pengujian efektivitas pupuk NPK dan cara aplikasi dilakukan bertujuan untuk mengetahui pola pertumbuhan tanaman strawberry. Penelitian menggunakan RAL (Rancangan Acak Lengkap) Faktorial dengan 3 kali ulangan. Faktor pertama yaitu Dosis pupuk NPK 12-6-24 dengan taraf $0 ; 1 \mathrm{~g}(\mathrm{~g} / \mathrm{L}) ; 2 \mathrm{~g} \mathrm{(g/L);} 3 \mathrm{~g} \mathrm{(g/L);} 4 \mathrm{~g}$ (g/L); dan pupuk NPK rekomendasi 16-16-16, $2 \mathrm{~g}(2 \mathrm{~g} / \mathrm{L})$. Faktor kedua yaitu cara aplikasi dengan taraf $\mathrm{A} 1$ (ditabur) dan A2 (dikocor). Data tinggi dan jumlah daun yang diperoleh dianalisis menggunakan Analysis of Variance aplikasi SPSS dan dilanjutkan dengan DMRT (Duncan Multiple Range Test) taraf $\alpha$ 5\%. Hasil pengujian pupuk NPK 12-6-24 terhadap pertumbuhan strawberry yang dibandingkan dengan NPK 16-16-16 sebagai pupuk rekomendasi memperlihatkan bahwa interaksi antara perlakuan dosis dan cara aplikasi tidak berpengaruh nyata, namun perlakuan tunggal dosis berpengaruh nyata terhadap parameter tinggi dan jumlah daun tanaman strawberry. NPK 12-6-24 dosis $4 \mathrm{~g}$ aplikasi granul (ditabur) efisien terhadap pertumbuhan tanaman strawberry secara keseluruhan apabila mempertimbangkan tenaga kerja, sedangkan NPK 12-6-24 dosis $2 \mathrm{~g}$ aplikasi kocor efisien apabila mempertimbangkan jumlah pupuk yang digunakan dan Perlakuan NPK 12-6-24 lebih efisien dibandingkan pupuk NPK 16-16-16 rekomendasi pada semua parameter
\end{abstract}

Kata Kunci: Aplikasi, Dosis, Pupuk NPK, Strawberry

\begin{abstract}
Nutrient management is one of determinants keys of fruit yield and quality. During this time, fertilizer recommendations for strawberry plants using NPK 16-16-16. NPK fertilization 16-16-16 is still insufficient, so farmers still add KNO3 fertilizer. Therefore, it is necessary to test the NPK fertilizer with different composition with higher K portion (NPK 12-6-24). Testing the effectiveness of NPK fertilizer and how the application is done aims to determine the growth pattern of strawberry plants. Research using RAL (Complete Random Design) Factorial with 3 repetitions. The first factor is Dose of NPK fertilizer 12-6-24 with level 0; $1 \mathrm{~g}(\mathrm{~g} / \mathrm{L}) ; 2$ $\mathrm{g}(\mathrm{g} / \mathrm{L}) ; 3 \mathrm{~g}(\mathrm{~g} / \mathrm{L}) ; 4 \mathrm{~g}(\mathrm{~g} / \mathrm{L})$; and NPK fertilizer recommendation 16-16-16, $2 \mathrm{~g}(2 \mathrm{~g} / \mathrm{L})$. The second factor is the way of application with level A1 (sown) and A2 (dikocor). High data and leaf number obtained were analyzed using Analysis of Variance of SPSS application and continued with DMRT (Duncan Multiple Range Test) levels $\alpha 5 \%$. The result of NPK 12-6-24 fertilizer test on strawberry growth compared to NPK 16-16-16 as fertilizer recommendation showed that the interaction between dosage treatment and application method did not have the real effect, but single dose treatment had a significant effect on high parameter and number of plant leaves strawberry. NPK 12-6-24 dose $4 \mathrm{~g}$ granule application (sown) is effective against the growth of strawberry plant as a whole when considering labor, while NPK 12-6-24 dose $2 \mathrm{~g}$ efficient leak application when considering the amount of fertilizer used and NPK Treatment 12-6-24 more efficient than NPK 16-1616 fertilizer recommendations on all parameters
\end{abstract}

Keywords: Application, Dose, NPK Fertilizer, Strawberry 


\section{PENDAHULUAN}

Strawberry merupakan salah satu komoditas buah subtropis yang berpotensi tinggi untuk dikembangkan di Indonesia. Kandungan gizi strawberry per $100 \mathrm{~g}$ buah yaitu energi $140 \mathrm{~kJ}$, karbohidrat $7.6 \mathrm{~g}$, lemak $0.5 \mathrm{~g}$, protein $0.8 \mathrm{~g}$, serat $1.7 \mathrm{~g}$, vitamin C $53 \mathrm{mg}$, dan air $90.6 \mathrm{~g}$. Selain kandungan gizi tinggi, buah strawberry juga mengandung ellagic acid, yang merupakan anti toksin, anti radikal bebas, anti karsinogenik, dan anti mutagen (Poincelot, 2004). Hal ini menjadikan peluang pasar buah strawberry semakin luas dengan nilai ekonomi tinggi.

Produksi strawberry dari petani, saat ini masih sangat kurang untuk memenuhi permintaan yang terus bertambah (Sutopo, 2016). Rendahnya produksi dikarenakan sifat tanaman strawberry yang sangat sensitif terhadap kondisi cuaca dan hama penyakit (Trejo-Téllez dan Gómez-Merino, 2014). Usaha yang dapat dilakukan untuk meningkatkan kuantitas dan kualitas produksi strawberry yaitu dengan meningkatkan performa tanaman strawberry. Pengelolaan hara merupakan salah satu faktor penentu hasil dan kualitas buah yang tinggi. Salah satu hara yang dapat membuat tanaman lebih tahan terhadap serangan penyakit yaitu hara $\mathrm{K}$ (kalium). Menurut Subandi (2013), tingkat serangan penyakit pada padi, jagung, ubi kayu, dan kedelai, akan menurun bila hara $\mathrm{K}$ cukup. Pengaruh positif hara $\mathrm{K}$ pada ketahanan tanaman terhadap penyakit terjadi melalui peningkatan pembentukan senyawa fenol yang bersifat fungisida serta menurunnya kandungan $\mathrm{N}$ anorganik dalam jaringan tanaman. Menurut Suharja (2009), tanaman yang kekurangan K, akan mengalami gangguan pengangkutan (translocation) karbohidrat dari daun ke organ lainnya sehingga hasil fotosintetis terakumulasi pada daun dan menurunkan kecepatan fotosintetis.

Selama ini, rekomendasi pupuk untuk tanaman strawberry menggunakan NPK 16-1616. Pemupukan NPK 16-16-16 masih kurang mencukupi, sehingga petani masih menambahkan pupuk $\mathrm{KNO}_{3}$. Oleh karena itu, perlu dilakukan pengujian terhadap pupuk NPK dengan komposisi berbeda, yaitu porsi $\mathrm{K}$ lebih tinggi (NPK 12-6-24). Penelitian ini selain menguji efektivitas pupuk NPK 12-6-24, mengkaji efektivitas dari cara aplikasi.
Pengujian ini perlu dilakukan untuk mengetahui potensi penggunaan pupuk dan cara aplikasi yang menguntungkan dalam hal produksi, kualitas, serta pengendalian hama dan penyakit, melalui pengaruhnya pada pertumbuhan tanaman strawberry lebih baik.

\section{BAHAN DAN METODE}

Penelitian dilaksanakan di Screen House SDG Strawberry Balai Penelitian Tanaman Jeruk dan Buah Subtropika KP Tlekung, Batu. Penelitian dimulai pada tanggal 10 januari - 09 Februari 2016.

\subsection{Bahan}

Bahan yang digunakan yaitu benih strawberry varietas earlibright V1 umur 14 hari setelah pemisahan dari susuan, pupuk NPK 16-16-16, NPK 12-6-24, media arang sekam, tanah, pupuk kandang, dan cocopeat 1:1:1:1, polybag berdiameter $20 \mathrm{~cm}$ dan tinggi $20 \mathrm{~cm}$, air PDAM, kertas HVS dan kertas karbon untuk mengukur luas daun metode gravimetri. Alat yang digunakan yaitu cangkul dan sekop, timbangan digital ketelitian 0,0001 g, beakerglass 500 dan $2000 \mathrm{~mL}$, penggaris ketelitian $1,0 \mathrm{~mm}$, oven suhu maksimum $200^{\circ} \mathrm{C}$

\subsection{Metode}

Rancangan penelitian yang digunakan adalah RAL (Rancangan Acak Lengkap) Faktorial dengan 3 kali ulangan. Faktor pertama yaitu Dosis pupuk NPK 12-6-24 dengan taraf $\mathrm{D} 0=0 ; \mathrm{D} 1=1 \mathrm{~g}(\mathrm{~g} / \mathrm{L}) ; \mathrm{D} 2=2 \mathrm{~g}$ (g/L); D3= $3 \mathrm{~g}(\mathrm{~g} / \mathrm{L}) ; \mathrm{D} 4=4 \mathrm{~g}(\mathrm{~g} / \mathrm{L})$; dan D5= pupuk NPK rekomendasi 16-16-16, 2 g (2 $\mathrm{g} / \mathrm{L})$. Faktor kedua yaitu cara aplikasi dengan taraf A1 (ditabur, dilakukan 1 bulan sekali) dan A2 ( dikocor, dilakukan satu minggu sekali, $250 \mathrm{~mL} / \operatorname{tanaman}$ ).

Data luas daun, massa basah dan massa kering di analisa menggunakan analisa proximat. Sedangkan pertambahan tinggi dan jumlah daun yang diperoleh dianalisis menggunakan Analysis of Variance aplikasi SAS. Apabila terdapat pengaruh perlakuan yang nyata, maka akan dilanjutkan dengan DMRT (Duncan Multiple Range Test) taraf a $5 \%$.

\section{HASIL DAN PEMBAHASAN}


Hasil pengujian pupuk NPK 12-6-24 terhadap pertumbuhan strawberry yang dibandingkan dengan NPK 16-16-16 sebagai pupuk rekomendasi (paket standard) memperlihatkan bahwa interaksi antara perlakuan dosis dan cara aplikasi tidak berpengaruh nyata terhadap parameter tinggi dan jumlah daun. Perlakuan tunggal aplikasi juga tidak berpengaruh, namun perlakuan tunggal dosis berpengaruh nyata terhadap parameter tinggi dan jumlah daun tanaman strawberry.

Tabel 3. 1 Pertambahan Tinggi Tanaman Strawberry akibat Pengaruh Dosis Pupuk NPK

\begin{tabular}{|c|c|c|c|}
\hline \multirow{2}{*}{$\begin{array}{c}\text { Perlakuan } \\
\text { Dosis }\end{array}$} & \multicolumn{3}{|c|}{ Pertambahan Tinggi (cm) } \\
\cline { 2 - 4 } & $1 \mathrm{MSP}$ & $2 \mathrm{MSP}$ & $3 \mathrm{MSP}$ \\
\hline D0 & $0,47 \mathrm{a}$ & $0,80 \mathrm{ab}$ & $0,92 \mathrm{abc}$ \\
\hline D1 & $0,62 \mathrm{a}$ & $0,95 \mathrm{a}$ & $1,03 \mathrm{a}$ \\
\hline D2 & $0,60 \mathrm{a}$ & $0,83 \mathrm{ab}$ & $0,93 \mathrm{ab}$ \\
\hline D3 & $0,43 \mathrm{a}$ & $0,76 \mathrm{ab}$ & $0,90 \mathrm{abc}$ \\
\hline D4 & $0,33 \mathrm{a}$ & $0,82 \mathrm{ab}$ & $0,97 \mathrm{c}$ \\
\hline D5 & $0,47 \mathrm{a}$ & $0,85 \mathrm{~b}$ & $0,90 \mathrm{bc}$ \\
\hline
\end{tabular}

Ket:Angka-angka yang diikuti oleh huruf yang berbeda pada kolom yang sama menunjukkan berbeda nyata menurut Uji DMRT a 5\%, MSP (Minggu Setelah Perlakuan).

Tabel 3. 2 Pengaruh Cara Aplikasi terhadap Pertambahan Tinggi Tanaman dan Interaksinya

\begin{tabular}{|l|c|c|c|}
\hline $\begin{array}{l}\text { Cara } \\
\text { Aplikasi }\end{array}$ & $1 \mathrm{MSP}$ & $2 \mathrm{MSP}$ & $3 \mathrm{MSP}$ \\
\hline A1 & 0,46 & 0,82 & $0,96 \mathrm{~b}$ \\
\hline A2 & 0,52 & 0,86 & $0,92 \mathrm{a}$ \\
\hline Interaksi & th & tn & tn \\
\hline
\end{tabular}

Ket:Angka-angka yang diikuti oleh huruf yang berbeda pada kolom yang sama menunjukkan berbeda nyata menurut Uji DMRT 5\%, MSP (Minggu Setelah Perlakuan).

Pertambahan tinggi tanaman menunjukkan bahwa pada umur 1 MSP perlakuan dosis belum berpengaruh terhadap tinggi tanaman. Pengaruh perlakuan tersebut mulai tampak pada 2 dan 3 MSP. Perlakuan D1 tinggi tanaman strawberry $0,95 \mathrm{~cm}$ berbeda nyata dengan D5 tinggi tanaman strawberry $0,85 \mathrm{~cm}$, tetapi berbeda tidak nyata dengan $\mathrm{D} 0$, D2, D3, dan D4 pada 2 MSP. Perlakuan D1 tinggi tanaman strawberry $1,03 \mathrm{~cm}$ berbeda nyata dengan D4 tinggi tanaman strawberry $0,97 \mathrm{~cm}$, tetapi berbeda tidak nyata dengan D0,
D2, D3, dan D5 pada 3 MSP (Tabel 3.1). Porsi K yang lebih tinggi pada pupuk NPK 126-24 memberikan pengaruh yang signifikan terhadap pertambahan tinggi tanaman strawberry, hal ini senada pada penelitian tanaman tembakau virginia penambahan unsur KNO3 dapat meningkatkan tinggi tanaman dibandingkan kontrol, namun jika aplikasi dosis diberikan hingga dua kali maka hasil yang diperoleh tidak berbeda nyata (Hutapea, A.S, dkk, 2014).

Perlakuan cara aplikasi granul (ditabur) secara tunggal berpengaruh nyata terhadap petambahan tinggi tanaman 3 MSP. Perlakuan cara aplikasi granul (ditabur) berbeda sangat nyata dengan perlakuan aplikasi dikocor. Minggu pertama dan kedua setelah perlakuan belum memberikan pengaruh terhadap pertambahan tinggi. Hal ini dikarenakan pelepasan hara pupuk granul berlangsung lebih lambat dibanding dikocor, sehingga efek yang ditimbulkan baru terlihat pada 3 MSP(Tabel 3.2). Sedangkan seluruh interaksinya antara dosis dan cara aplikasi keseluruhan menunjukkan perbedaan yang tidak nyata.Aplikasi kocor belum memberikan efek positif terhadap pertambahan tinggi dikarenakan mudah tercuci dan hilang, terutama pada musim penghujan. Sebagaimana menurut Shaviv (2003), pupuk granul dapat melepas unsur hara lambat sehingga dapat meningkatkan efisiensi penggunaan unsur hara oleh tanaman dan meminimalkan kehilangan unsur hara karena degradasi atau terbawa hanyut oleh air.

Tabel 3.3 Jumlah Daun Tanaman Strawberry akibat Pengaruh Dosis Pupuk NPK

\begin{tabular}{|c|c|c|c|}
\hline \multirow{2}{*}{ Perlakuan } & & $\begin{array}{c}\text { Cara } \\
\text { Aplikasi }\end{array}$ & \\
\cline { 2 - 4 } & $1 \mathrm{MSP}$ & $2 \mathrm{MSP}$ & $3 \mathrm{MSP}$ \\
\hline $\mathrm{D} 0$ & $1,00 \mathrm{ab}$ & $1,50 \mathrm{ab}$ & $1,67 \mathrm{ab}$ \\
\hline $\mathrm{D} 1$ & $0,67 \mathrm{a}$ & $1,50 \mathrm{ab}$ & $1,67 \mathrm{ab}$ \\
\hline $\mathrm{D} 2$ & $0,83 \mathrm{~b}$ & $1,33 \mathrm{~b}$ & $1,50 \mathrm{~b}$ \\
\hline $\mathrm{D} 3$ & $0,33 \mathrm{a}$ & $0,80 \mathrm{a}$ & $1,20 \mathrm{a}$ \\
\hline D4 & $0,67 \mathrm{ab}$ & $1,67 \mathrm{~b}$ & $1,83 \mathrm{ab}$ \\
\hline D5 & $0,67 \mathrm{ab}$ & $1,50 \mathrm{ab}$ & $1,50 \mathrm{ab}$ \\
\hline
\end{tabular}

Ket: angka-angka menunjukkan berbeda nyata menurut Uji DMRT a 5\%, MSP (Minggu Setelah Perlakuan). 
Tabel 3.4 Jumlah Daun Akibat Cara Aplikasi Pupuk dan Interaksinya

\begin{tabular}{|l|l|l|l|}
\hline Perlakuan & \multicolumn{3}{|c|}{ Cara Aplikasi } \\
\hline A1 & 0,46 & 0,82 & 0,96 \\
\hline A2 & 0,52 & 0,86 & 0,92 \\
\hline Interaksi & tn & tn & tn \\
\hline
\end{tabular}

Ket: angka-angka menunjukkan berbeda nyata menurut Uji DMRT a 5\%, MSP (Minggu Setelah Perlakuan).

Jumlah daun pada perlakuan D1 dan D3 berbeda nyata dengan $\mathrm{D} 2$, tetapi berbeda tidak nyata dengan D0, D4, dan D5 terhadap jumlah daun pada 1 MSP. Perlakuan D3 berbeda nyata dengan $\mathrm{D} 2$ dan $\mathrm{D} 4$, tetapi berbeda tidak nyata dengan D0, D1, dan D5 pada 2 MSP. Perlakuan D3 berbeda nyata dengan D2, tetapi tidak berbeda nyata dengan D0, D1, D4, dan D5 pada 3 MSP. Dosis 2 g NPK 12-6-24 baik untuk pertumbuhan daun (Tabel 3.3). Cara aplikasi di kocor dan di tabur tidak memberikan perbedaan yang nyata terhadap pertambahan jumlah daun, begitu pula interasi antara dosis dan aplikasinya (Tabel 3.4). Tersedianya kandungan Ca yang lebih tinggi pada paket pupuk rekomendasi yang dibandingkan dengan paket pupuk yang diuji menjelaskan pertumbuhan tinggi tanaman dan jumlah daun yang sama baik, hal ini berkaitan dengan peran $\mathrm{Ca}$ yaitu memicu jalur sinyal pertumbuhan, perkembangan, dan tanggapan cekaman biotik maupun abiotik. Kalsium juga dapat meningkatkan efisiensi penggunaan $\mathrm{N}$ serta meningkatkan kekuatan dan ketebalan dinding sel (Trejo-Téllez dan Gómez-Merino, 2014).

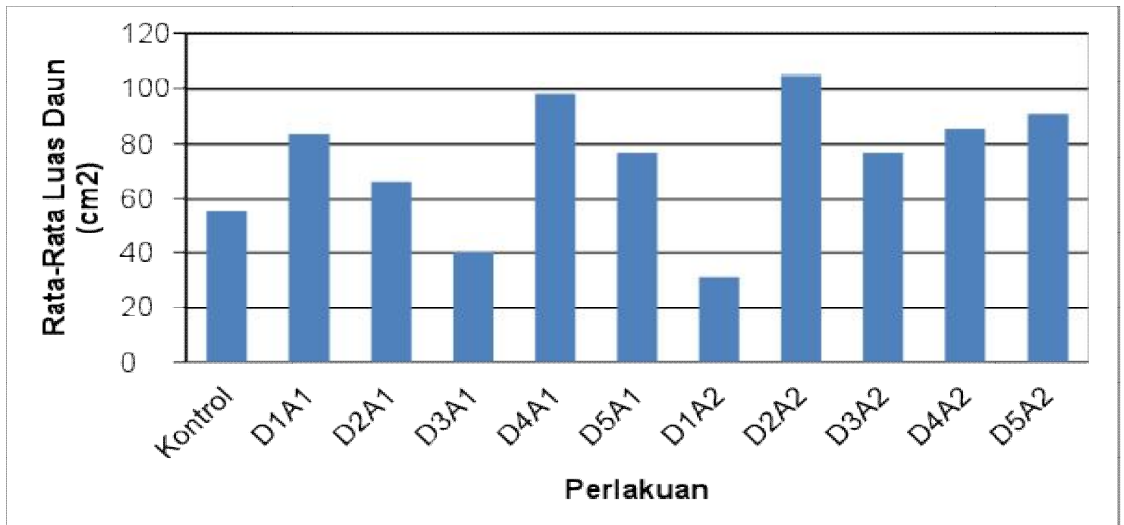

Gambar 3.1 Rata-Rata Luas Daun Tanaman Strawberry 3 MSP akibat Perlakuan Dosis dan Cara Aplikasi Pupuk NPK

Dari Hasil pengamatan diperoleh luas daun tertinggi pada perlakuan D2A2 dan D4A1. Perlakuan D2A2 lebih efisien dibanding perlakuan D4A1 apabila melihat dari jumlah pupuk yang diberikan (Gambar 3.1). Namun apabila yang menjadi pertimbangan adalah tenaga kerja, maka perlakuan D4A1 menjadi lebih efisien karena hanya diaplikasikan satu kali perbulan, sedangkan perlakuan D2A2 diaplikasikan perminggu dan masih harus melarutkan pupuk. Rata-rata luas daun Kontrol,
D1A1, D2A1, D3A1, dan D5A1 pada gambar menunjukkan nilai yang fluktuatif, namun massa kering daun menunjukkan nilai yang hampir sama artinya asimilat dalam daun pada perlakuan tersebut sama besar.Penambahan pupuk kalium dibutuhkan dalam proses fisiologi tanaman terutama pada proses fotosintesis. Hal ini sesuai dengan penelitian Safuan dan Bahrun (2012), bahwa penambahan kalium dapat meningkatkan luas daun dan lingkar batang pada tanaman melon. 
Palupi, et al. 2017

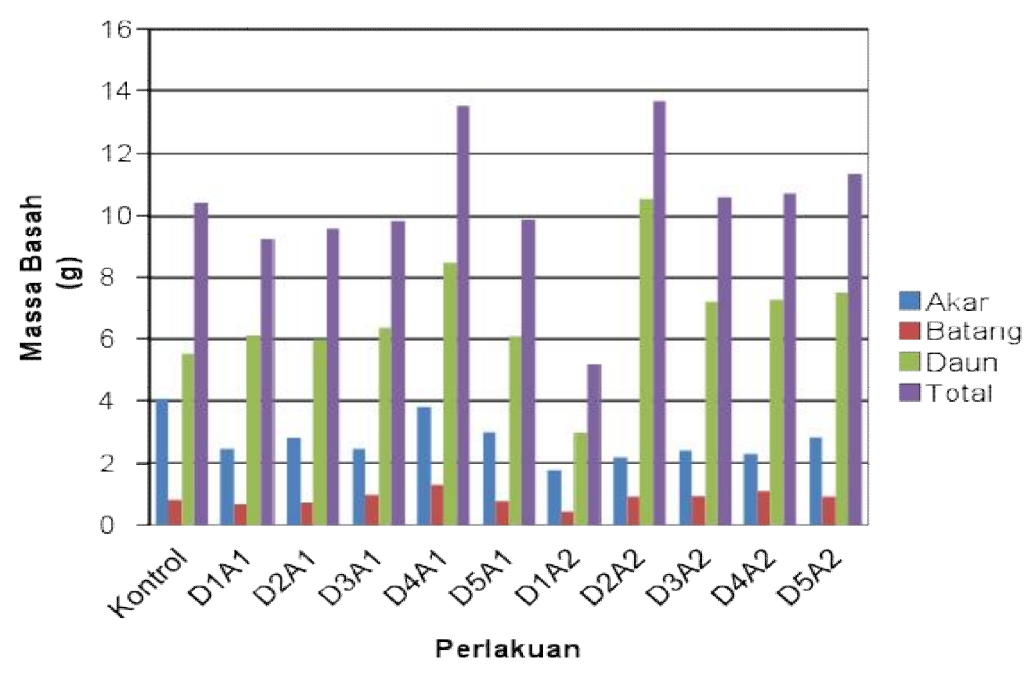

Gambar 3.2 Massa Basah Tanaman Strawberry 3 MSP akibat Perlakuan Dosis dan Cara Aplikasi Pupuk NPK

Massa basah total tertinggi pada perlakuan D2A2 dan D4A1 (Gambar 3.2). Perlakuan D4A1 lebih efisien, karena menunjukkan pola distribusi hasil fotosintat yang lebih seimbang jika dibanding D2A2 yaitu massa basah daun tinggi, namun tidak demikian dengan akar dan batangnya. Hasil fotosintetis yang terakumulasi pada daun akan menurunkan kecepatan fotosintesis karena pengangkutan (translokasi) karbohidrat dari daun ke organ lainnya terhambat (Suharja, 2009).

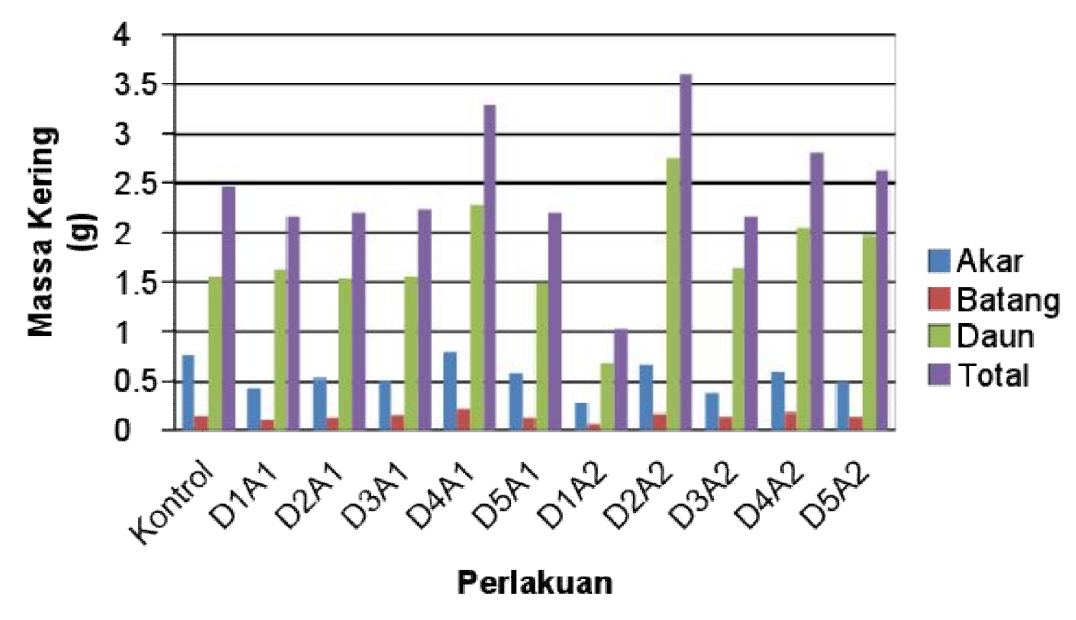

Gambar 3.3 Massa Kering Tanaman Strawberry 3 MSP akibat Perlakuan Dosis dan Cara Aplikasi Pupuk NPK

Massa kering tertinggi pada perlakuan D4A1 dan D2A2. Perlakuan D2A2 lebih efisien daripada D4A1 apabila melihat jumlah pupuk yang digunakan. Namun perlakuan D4A1 menjadi lebih efisien apabila melihat dari segi tenaga kerja yang digunakan serta pola distribusi hasil fotosintesis(Gambar 3.3). Perlakuan NPK 12-6-24 lebih efisien dibandingkan pupuk NPK 16-16-16 rekomendasi pada semua parameter, karena keseimbangan unsur haranya baik untuk pertumbuhan. Pengaruh formula pemupukan terhadap hasil pertumbuhan tanaman tergantung kebutuhan tanaman (Suyamto dkk., 2015). 
Pupuk majemuk dengan kandungan $\mathrm{K}$ tinggi baik bagi pertumbuhan vegetatif tanaman strawberry. Unsur Kalium berperan dalam pembentukan pati, mengaktifkan enzim, pembukaan stomata (mengatur pernapasan dan penguapan), proses fisiologis tanaman, proses metabolis sel, mempengaruhi penyerapan unsur lain, meningkatkan daya tahan terhadap penyakit serta berperan dalam perkembangan akar (Pratiwi, 2014). Gangguan pada pembukaan dan penutupan stomata akibat tanaman kahat $\mathrm{K}$ dapat menurunkan aktivitas fotosintetis karena terganggunya pemasukan $\mathrm{CO}_{2}$ ke daun. Ada hubungan erat antara kadar $\mathrm{K}$ dalam jaringan dengan asimilasi $\mathrm{CO}_{2}$ pada tanaman. Tanaman kekurangan $\mathrm{K}$, maka pengangkutan (translokasi) karbohidrat dari daun ke organ lainnya terhambat sehingga hasil fotosintetis terakumulasi pada daun dan menurunkan kecepatan fotosintesis (Suharja, 2009). Kalium mampu meningkatkan berat kering akar $(50 \%)$, berat kering total $(50 \%)$, kadar air daun $(8,2 \%)$ tanaman strawberrydibandingkan Kontrol yang tidak menerima $\mathrm{KNO}_{3}$ (Yildirim dkk., 2009).

Penelitian oleh Ebrahim

menunjukkan bahwa unsur $\mathrm{K} \mathrm{0,3} \mathrm{g} / \mathrm{L}$ mampu meningkatkan hasil tanaman, bobot basah dan kering akar serta panjang akar tanaman strawberry. NPK 12-6-24 dosis $2 \mathrm{~g}$ mengandung unsur $0,4 \mathrm{~g} \mathrm{~K}$ sedangkan dosis di bawah dan di atas $2 \mathrm{~g}$ mengandung unsur kurang dari 0,2 g dan lebih dari 0,6. Hal ini menjelaskan bahwa perlakuan D1, D3, dan D4 tidak berbeda dengan Kontrol karena dosis D1 masih belum mencukupi kebutuhan $\mathrm{K}$ tanaman sedangkan dosis D3 dan D4 melebihi kebutuhan tanaman (jenuh). Perlakuan D4A1 menjadi lebih baik daripada lainnya meskipun dosis tinggi, hal ini dikarenakan pupuk lepas lambat memberikan pelepasan berkelanjutan pada jangka waktu lebih lama (Shaviv, 2003; Han, 2009).

Selain komposisi NPK yang berbeda, terdapat susunan hara lain yang berbeda antara paket pupuk diuji dengan paket pupuk rekomendasi. Komposisi paket pupuk yang diuji (NPK 12-6-24 + $\left.2 \mathrm{MgO}+3 \mathrm{CaO}+14 \mathrm{SO}_{3}\right)$ sedangkan paket rekomendasi (NPK 16-16-16 $+1,5 \mathrm{MgO}+5 \mathrm{CaO}$ ). Adanya unsur $\mathrm{S}$ dan kandungan unsur $\mathrm{Mg}$ yang lebih besar pada paket pupuk yang diuji (NPK 12-6-24) mampu memberikan pertumbuhan strawberry yang lebih baik daripada paket pupuk rekomendasi (NPK 16-16-16). Unsur S berperan dalam proses pembentukan klorofil sedangkan unsur Mg merupakan penyusun molekul klorofil (Yildirim dkk., 2009; Erdal dkk., 2006). Unsur Ca berperan dalam pemberian respon atau tanggapan terhadap cekaman biotik dan abiotik termasuk patogen (Trejo-Téllez dan Gómez-Merino, 2014).

Penelitian oleh Andriolo dkk. (2011) menunjukkan penurunan jumlah daun, tunas, dan massa kering akar tanaman strawberry akibat peningkatan konsentrasi $\mathrm{N}$ dalam larutan nutrisi. Janisch dkk. (2012) juga menyebutkan bahwa peningkatan konsentrasi larutan $\mathrm{N}$ dari $0,28 \mathrm{~g} / \mathrm{L}$ dapat mengurangi pertumbuhan mahkota, akar, dan indeks luas daun strawberry. Respon perkembangan tanaman fase vegetatif terhadap tingkat pemupukan $\mathrm{N}$ dikendalikan oleh ketersediaan $\mathrm{N}$ di zona perakaran. Respon tanaman strawberry fase vegetatif positif apabila tanaman strawberry memerlukan $\mathrm{N}$ dalam jumlah tinggi. Hal ini terjadi antara awal berbunga dan akhir panen. Aplikasi pupuk $\mathrm{N}$ setelah tanam (ketika persyaratan $\mathrm{N}$ rendah) akan menimbulkan efek merugikan terhadap perkembangan awal tanaman strawberry sehingga pemupukan $\mathrm{N}$ harus memperhatikan yang dibutuhkan tanaman (Neuweiler dkk., 2001).

NPK 12-6-24 dosis $2 \mathrm{~g}$ mengandung unsur $0,24 \mathrm{~g} / \mathrm{L} \mathrm{N}$ sedangkan NPK 16-16-16 dosis $2 \mathrm{~g}$ (D5) mengandung unsur $0,32 \mathrm{~g} / \mathrm{L} \mathrm{N}$. Massa kering D3A2, D4A2, dan D5A2 lebih rendah dari D2A2 (NPK 12-6-24 dosis $2 \mathrm{~g}$ aplikasi kocor). Menurut Trejo-Tellez dan Gomez-Merino (2014), unsur P memiliki efek terhadap kualitas buah dibandingkan hasil dan produktivitas. Sehingga tidak memberikan pengaruh yang berarti terhadap pertumbuhan vegetatif tanaman strawberry walaupun berbeda konsentrasi yang diberikan.

Adanya sedikit fluktuatif hasil kemungkinana dapat disebabkan oleh respon jaringan masing-masing tanaman berbeda. Unsur makro dan mikro dapat memberikan pengaruh positif juga negatif pada produksi tanaman strawberry tergantung genetik tanaman, lingkungan, karakteristik tanah, aplikasi hara, status hara, serta kebutuhan tanaman. Analisis daun dapat membantu menilai status hara (kurang, cukup, toksin) sehingga akurat menentukan kebutuhan 
pupuk maupun memodifikasi program pemupukan (Lester dkk., 2010; Suriadikarta, 2004).

\section{KESIMPULAN}

Hasil penelitian dapat diberi kesimpulan bahwa NPK 12-6-24 dengan dosis $4 \mathrm{~g}$ dengan aplikasi granul (ditabur) efisien terhadap pertumbuhan tanaman strawberry secara keseluruhan. Sedangkan NPK 12-6-24 dosis $2 \mathrm{~g}$ dengan aplikasi kocor efisien apabila mempertimbangkan jumlah pupuk yang digunakan.

Perlakuan NPK 12-6-24 lebih efisien dibandingkan pupuk NPK 16-16-16 rekomendasi pada semua parameter

\section{UCAPAN TERIMAKASIH}

Ucapan terimakasih kepada teknisi Balitjestro Bpk. Sumarsono dan Dwi kurnila sari sebagai mahasiswi bimbingan PKL yang membantu proses penelitian hingga selesai.

\section{DAFTAR PUSTAKA}

Andriolo, J., L. Erpen, F. Cardoso, C. Cocco, C. Casagrande, dan Janisch. 2011. Nitrogen Levels in The Cultivation of Strawberries in Soilless Culture. Hortic. Bra 29: 516-519.

Ebrahim, R., M. K. Souri, F. Ebrahimi, dan M. Ahmadizadeh. 2012. Growth and Yield of Strawberries under Different Potassium Concentrations of Hydroponic System in Three Substrates. World Appl. Sci. J. 16: 1380-1386.

Erdal, I., K. Kepenek, dan I. Kizilgoz. 2006. Effect of Elemental Sulphur and Sulphur Containing Waste on The Iron Nutrition of Strawberry Plants Grown in A Calcareous Soil. Biol. Agric. Hort 23: 263-272.

Han, X., S. Chen, dan X. Hu. 2009. Controlledrelease Fertilizer Encapsulated by Starch/Polyvinyl Alcohol Coating. Desalination. 240: 21-26.
Hutapea,A.S, Hadiastono, T, dan Martosudiro,M., 2014. Pengaruh Pemberian Pupuk Kalium (KNO3) Terhadap Infeksi Tobacco Mosaik Virus (TMV) Pada Beberapa Varietas Tembakau Virginia (Nicotiana Tabacum L). Jurnal HPT, Vol 2 :1., ISSN:2338-4336.

Janisch, D., J. Andriolo, V. Toso, D.S. Ferreira, dan J. Maronez De Souza. 2012. Nitrogen for Growth of Stock Plants and Production of Strawberry Runner Tips. Bragantia Campinas 71: 394-399.

Lester, G.E., Jifon, J.L., Makus, D.J. 2010. Impact of Potassium Nutrition on Food Quality of Fruits and Vegetables: A Condensed and Concise Review of The Literature. Better Crops, 94: 1821.

Neuweiler, N. 2001. Ground Cover and Nitrogen Management in Strawberry Cultivation under Swiss Humid Climate Conditions. Disertasi. [Online]. Tersedia: http://Ecollection.Library.Ethz.Ch/Eserv /Eth:24407/Eth-24407-01.Pdf.

Poincelot, R. P. 2004. Sustainable Horticulture Today and Tomorrow. New Jersey: Prentice Hall. 870 Hal.

Pratiwi, R. 2014. Peran Unsur Hara Kalium (K) Bagi Tanaman. [Online]. Tersedia: Http://www.bbpp-lembang.info diakses pada 05 Februari 2017.

Saufan L.A dan Bahrun, A. 2012. Pengaruh Pupuk Organik dan Kalium Terhadap Pertumbuhan dan Produksi Tanaman Melon (Cucumis melo.L). Jurnal Agroteknos. Vol 2: 2. hal: 69-76. ISSN:2087-7706

Shaviv, A., S. Raban, dan E. Zaidel. 2003. Modeling Controlled Nutrient Release from Polymer Coated Fertilizers: Diffusion Release from Single Granules. Environ. Sci. Technol. 37: 2251-2256.

Subandi. 2013. Peran dan Pengelolaan Hara Kalium untuk Produksi Pangan di 
Palupi, et al. 2017

Indonesia. Pengembangan Inovasi Pertanian 6 (1): 1-10.

Suharja. 2009. Biomassa, Kandungan Klorofil dan Nitrogen Daun Dua Varietas Cabai (Capsium Annum L) pada Berbagai Perlakuan Pemupukan. Tesis. Surakarta: universitas sebelas maret.

Suriadikarta, D. A., D. Setyorini, dan W. Hartatik. 2004. Petunjuk Teknis Uji Mutu dan Efektivitas Pupuk Alternatif Anorganik. Bogor: Balai Penelitian Tanah.

Sutopo. 2016. Teknologi Budidaya Stroberi di Lahan. [Online]. Tersedia: balitjestro. litbang.pertanian.go.id diakses pada 03 Februari 2016.

Suyamto, M. Saeri, D. P., Saraswati, dan Robi'in. 2015. Verifikasi Dosis Rekomendasi Pemupukan Hara Spesifik Lokasi untuk Padi Varietas Hibrida. Penelitian Pertanian Tanaman Pangan 34 (3): 165-245.

Trejo-Tellez, L.I. dan Gomez-Merino, F.C. 2014. Nutrient Management in Strawberry: Effects on Yield, Quality and Plant Health. [Online]. Nova Science Publishers, Inc.@https://www.researchgate.net/pu blication/26803 7619.

Yildirim, E., H. Karlidag, dan M. Turan. 2009. Mitigation of Salt Stress in Strawberry by Foliar $\mathrm{K}, \mathrm{Ca}$, and $\mathrm{Mg}$ Nutrient Supply. Plant Soil Environ 55: 213221. 